\title{
CD80 Insights as Therapeutic Target in the Current and Future Treatment Options of Frequent-Relapse Minimal Change Disease
}

\author{
Yoong Mond Teh $\mathbb{D}^{1},{ }^{1}$ Soo Kun Lim $\mathbb{D}^{2},{ }^{2}$ Norhana Jusoh $\mathbb{D}^{1,3}$ Kahar Osman $\mathbb{D}^{1}$, \\ and Siti Aisyah Mualif $\mathbb{D}^{1,3}$ \\ ${ }^{1}$ School of Biomedical Engineering and Health Sciences, Faculty of Engineering, Universiti Teknologi Malaysia (UTM), \\ Johor Bahru, Malaysia \\ ${ }^{2}$ Renal Division, Department of Medicine, Faculty of Medicine, University of Malaya (UM), Kuala Lumpur, Malaysia \\ ${ }^{3}$ Medical Device and Technology Centre (MEDiTEC), Universiti Teknologi Malaysia, Malaysia
}

Correspondence should be addressed to Siti Aisyah Mualif; aisyahmualif@utm.my

Received 12 November 2020; Accepted 26 December 2020; Published 6 January 2021

Academic Editor: Nisreen Abu Shahin

Copyright (c) 2021 Yoong Mond Teh et al. This is an open access article distributed under the Creative Commons Attribution License, which permits unrestricted use, distribution, and reproduction in any medium, provided the original work is properly cited.

\begin{abstract}
Minimal change disease (MCD) is the most common cause of idiopathic nephrotic syndrome in children, and it is well known for its multifactorial causes which are the manifestation of the disease. Proteinuria is an early consequence of podocyte injury and a typical sign of kidney disease. Steroid-sensitive patients react well with glucocorticoids, but there is a high chance of multiple relapses. CD80, also known as B7-1, is generally expressed on antigen-presenting cells (APCs) in steroid-sensitive MCD patients. Various glomerular disease models associated with proteinuria demonstrated that the detection of CD80 with the increase of urinary CD80 was strongly associated closely with frequent-relapse MCD patients. The role of CD80 in MCD became controversial because one contradicts finding. This review covers the treatment alternatives for MCD with the insight of CD80 as a potential therapeutic target. The promising effectiveness of CD20 (rituximab) antibody and CD80 inhibitor (abatacept) encourages further investigation of CD80 as a therapeutic target in frequent-relapse MCD patients. Therapeuticbased antibody towards CD80 (galiximab) had never been investigated in MCD or any kidney-related disease; hence, the role of CD80 is still undetermined. A new therapeutic approach towards MCD is essential to provide broader effective treatment options besides the general immunosuppressive agents with gruesome adverse effects.
\end{abstract}

\section{Minimal Change Disease Background}

Minimal change disease (MCD) is the most common cause of idiopathic nephrotic syndrome in children [1]. MCD is slightly more common in Asia and has a male predominance than woman (approximately $2: 1$ ) [2]. The majority of the nephrotic syndrome patients show MCD on histopathology diagnosis (80\%) [3]. Observations by Shalhoub back in 1974 resulted in a strong relationship between the traditional view of MCD and circulating mediators produced by abnormal T cells [4]. One of the observations includes MCD is associating with Hodgkin disease and responding towards immunosuppressive drugs that suppress cell-mediated immunity. However, the exact pathogenesis of MCD is still unknown today $[4,5]$. The theory of circulating mediators was supported by studies showing that supernatants of $\mathrm{T}$ cell hybridoma lines from MCD patients were able to trigger foot process effacement (podocyte injury) and proteinuria condition in a rat model [6]. There was vast evidence suggesting different aspects of $\mathrm{T}$ cell regulation and function for causing podocyte injury in MCD [5]. There were hypotheses for the pathogenesis of MCD with a central focus on podocytes that are shifted from T cells [7]. MCD and focal segmental glomerulosclerosis (FSGS) are the two most common causes of nephrotic syndrome in the pediatric population [8]. There was a high rate of disease relapse during adulthood, despite the availability of potent immunosuppressive agents [9]. It is crucial to develop novel MCD-based treatment because for the past few decades the main treatment options remain, and it is not beneficial to a certain group of patients. 
Proteinuria is an early consequence of podocyte injury and is a typical sign of kidney disease [10]. Proteinuria is defined as the clinical presentation of $\mathrm{MCD}$, a range of proteinuria in children $>40 \mathrm{mg} / \mathrm{m}^{2 /} \mathrm{h}$ or $>2 \mathrm{~g} /$ day, accompanied by hypoalbuminemia (serum albumin $<2.5 \mathrm{~g}$ ) and hypercholesterolemia [11]. In adults, nephrotic range proteinuria is defined as proteinuria of more than $3.5 \mathrm{mg} /$ day. Infections could trigger subsequent relapses of MCD [12]. Complete remission (CR) is defined as proteinuria $<166 \mathrm{mg} / 1.73 \mathrm{~m}^{2}$ / day or $<4 \mathrm{mg} / \mathrm{m}^{2} / \mathrm{h}$ or urine protein/creatinine ratio $<0.2$ $\mathrm{mg} / \mathrm{g}$ for more than 3 days and serum albumin $>3.5$. Partial remission (PR) is defined as proteinuria $>166 \mathrm{mg} / 1.73 \mathrm{~m}^{2} /$ day $\left(<4 \mathrm{mg} / \mathrm{m}^{2} / \mathrm{h}\right)$ but less than $2 \mathrm{~g} /$ day $\left(<40 \mathrm{mg} / \mathrm{m}^{2} /\right.$ day $)$ and serum albumin $>2.5 \mathrm{~g}$ or reduction in proteinuria $>50$ $\%$ from baseline [1]. Steroid-sensitive nephrotic syndrome (SSNS) is the normalization of proteinuria within 4 weeks of initiation of a standard dose of oral prednisolone [1]. The relapse of nephrotic syndrome is a condition after an initial response, reappearance of proteinuria $>40 \mathrm{mg} / \mathrm{m}^{2} / \mathrm{h}$ for 3 consecutive days. Infrequent relapse is the reappearance of proteinuria less than 3 times in a year, while frequent relapse is the reappearance of proteinuria around two or more times within 6 months or 4 relapses in the year following the initial therapy [1]. Steroid resistance (SR) is a condition that fails to respond to daily oral prednisolone to induce inadequate remission doses after 4 weeks of treatment in children while in adults it is classified as steroid resistance after 16 weeks of no response towards oral prednisolone at a dose of $1 \mathrm{mg} / \mathrm{kg} /$ day within 16 weeks [1]. Different responses of MCD patients towards glucocorticoid medication and successfully staying in remission decided the chance of recovery and back to full health.

Podocytes are highly specialized cells that cover the glomerulus, as the critical unit cells of the filtration barrier in the glomerulus; normal kidney function relies on healthy podocytes [13]. Podocytes maintain the physiological stresses at the same time they adapt to preserve function. The cytoskeletal actin system maintains podocyte foot process (large body cell with major cytoskeleton-linked cellular processes [13]), and abnormalities of the podocyte actin system lead to podocyte effacement [14]. The inability to regenerate or proliferate of podocytes leads to a decrease in cell number, but podocytes display a remarkable ability to recover from effacement and to reform the interdigitating foot process after an effective pharmacological intervention [15]. As long as the podocytes are not lost, they manifest a remarkable ability to recover the foot process quickly; this ability matches the description of MCD [15]. This phenomenon of podocyte recovery gives hope to the therapeutic field as the mouse model displays rapid but reversible foot process effacement and proteinuria. Nevertheless, podocyte foot process effacement was reported not correlated with the level of proteinuria in human glomerulopathies [16].

\section{CD80/B7-1}

CD80, also known as B7-1, is generally expressed on antigenpresenting cells (APCs) in steroid-sensitive MCD patients. Various glomerular disease models associated with protein- uria have reported the detection of CD80 [17]. The activation of CD80 on APCs and its binding to the CD28 receptor on $\mathrm{T}$ cells have a crucial role in $\mathrm{T}$ cell activation [7]. The binding of CD80 to cytotoxic T lymphocyte-associated- (CTLA-) 4 terminates the $\mathrm{T}$ cell response [18] while the CTLA-4 is expressed on the membrane of the Foxp $3+\mathrm{T}$ regulatory cell (Treg) and Treg may further inhibit the immune response by the release of soluble CTLA-4 which also has a function to suppress CD80 expression on APCs. CD80 expression is inhibited by CTLA- 4 and IL-10, which caused the remission of the proteinuria [18]. The impaired function of Tregs was observed in MCD patients [19]. Lipopolysaccharide (LPS) induced the elevation of CD80 expression on podocytes by binding to Toll-like receptor- (TLR-) 4 in association with the development of proteinuria and foot process effacement. A similar condition of CD80 expression was also found in cultured podocytes with disorganization of the actin cytoskeleton [20]. T cell cytokines such as IL-13 and polyinosinic:polycytidylic acid could also induce the expression of CD80 [21]. It was verified by immunofluorescence assay that podocytes expressed CD80 with a molecular weight of $53 \mathrm{kDa}$, which is the same as that of CD80 on the membrane, rather than the soluble $\mathrm{CD} 80$, which is $23 \mathrm{kDa}$ [22].

Clinical studies reported that CD80 is expressed in podocytes in MCD and FSGS [22-24], but these findings did not match the result of other clinical studies. In fact, in the studies of Novelli et al., the authors reported that B7-1 was not detected by the immunostaining method, yet B7-1 was still detected in infiltrating inflammatory cells, which provides a strong argument of the negative results [20]. Despite a study providing a controversial conclusion of CD80 not being detected, many studies argue its usefulness. One of the most reliable observations is that B7-1-deficient mice did not develop proteinuria after LPS injections, while the mice with severe combined immunodeficiency (SCID) became proteinuric and had increased B7-1 immunostaining on podocytes [25]. By using immunofluorescence, CD80 was observed primarily expressed on the surface of podocytes [22], based on the observation, since FSGS caused severe damage to the podocyte. Thus, the expression of CD80 was declined, which leads to urine CD80 that is less in MCD patients. Low level or zero levels of CD80 detection could be the reason why the study indicated that CD80 is only correlated with MCD but not FSGS [26]. In other words, healthy podocytes determine the amount of CD80 being expressed; the loss of podocytes also indicates that no level of CD80 is being expressed. CTLA-4, a protein receptor that binds with CD80 and downregulates the response of $\mathrm{CD} 80$, has been suggested as a potential treatment for glomerular disease [23].

The current treatment of chronic kidney disease mainly targets optimizing renal and heart risk factors instead of being kidney oriented [27]. The current treatment for MCD largely relies on immunosuppressant drugs by correcting lymphocyte dysfunction, especially $\mathrm{T}$ cells. Glucocorticoid was reported to be useful towards MCD patients mainly because of the glucocorticoid receptors on kidney cells [28]. CR is achieved in $80 \%-90 \%$ of children with MCD after treatment with an immunosuppressant, but the steroid mechanism is still unknown [7]. The responsiveness towards 
corticosteroids is different between individuals; adults often showed delayed response by 8-16 weeks to corticosteroids and approximately $65 \%-80 \%$ of adults with MCD will relapse within the first 3-6 months after remission $[29,30]$. Moreover, 25-30\% adults with MCD have frequent relapse; there is a substantial number of patients that have poor long-term result towards corticosteroids and usually suffer from frequent relapses which eventually lead to renal impairment $[31,32]$.

\section{Treatment Options in MCD}

Prednisolone (Table 1) is undoubtedly the most common treatment for MCD for both children and adults during early onset, while frequent-relapse patients will be given another drug to expect a remission. Oral prednisolone is given in a dose between $60 \mathrm{mg} / \mathrm{m}^{2} /$ day and $80 \mathrm{mg} /$ day for 6 weeks as a treatment for children with first episode of MCD while the adult is treated with prednisolone at a dose of $1 \mathrm{mg} / \mathrm{kg} / \mathrm{wt}$./day daily or $2 \mathrm{mg} / \mathrm{kg} /$ day on alternate days [1]. Prednisolone is also frequently reported to be used in combination with other agents as treatment options (Table 1). It was reported that single daily dosing is as effective as multiple daily dosing in maintaining remission in nephrotic syndrome children [33]. As part of the limitation of prednisolone in Table 1, its mode of mechanism to achieve remission of nephrotic syndrome is still unknown [34]. Various speculations of hypothesis explain the mechanism of prednisolone against MCD patients; most of it went beyond the typical anti-inflammatory or immunosuppressive actions because glomerular inflammation is mostly absent in SSNS [34].

Levamisole (Table 1) has been used as a treatment in some studies for MCD children [35]. Levamisole has promising results to maintain remission in children [36], but there is no evidence to explain this medication's mode of action at the molecular level (Table 1) [37]. Speculation of the effectiveness of levamisole could be the direct actions on podocytes [38]. Recent studies reported that levamisole significantly improves the relapse-free rate in children with frequent relapses or steroid dependency [39-41]; this outcome shows the ability of levamisole in preventing the relapses.

For the past 30 years, cyclophosphamide (CYC) and chlorambucil (CHL) as alternative of CYC have been used to treat children with relapsing SSNS (Table 1) [42]. A randomized trial showed that prolonging the duration from 8 to 12 weeks did not make any changes in relapses rate [43]. A preferred approach for frequently relapsing or steroid-dependent MCD in adults and children is the use of cyclophosphamide [44]. Oral cyclophosphamide at $1-2 \mathrm{mg} / \mathrm{kg}$ per day is initiated after reattaining a remission with prednisone [44]. However, the cumulative dose of cyclophosphamide should be monitored in the course of the given 8-12 weeks of medication because it is associated with adverse effect in Table 1 [45]. It was reported in another study that intravenous cyclophosphamide and oral prednisolone were as effective as the combination of intravenous dexamethasone together with cyclophosphamide and prednisolone oral therapy regarding its ability to induce remission in patients with steroidresistant nephrotic syndrome [46]. In adults, cyclophosphamide or calcineurin inhibitors have been used with up to $75 \%$ response rate [47]. The nonrelapse rate for the CYC group was $60 \%$ compared with a $24 \%$ nonrelapse rate in the steroid group [48].

Compared to cyclosporine, Mycophenolate Mofetil (MMF) is a less toxic adjuvant agent (Table 1) for remission maintenance in childhood-onset relapsing or steroiddependent MCD compared to cyclosporine [49-51] with the tendency towards a higher risk of relapse in patients treated with MMF [49]. Mycophenolate is shown to be a promising alternative treatment for adult MCD patients in case series [50, 52-54]. MMF was reported to be effective in lupus nephritis but not as effective in primary glomerulonephritis [53]. However, this outcome might be controversial with the studies of Dimkovic et al., as the authors reported that MMF proved to be efficient in $70 \%$ of high-risk patients with primary glomerulonephritis [54]. Studies by Fujinaga et al. (2009) suggested a similar result with Baglio et al. (2006) that MMF may not necessarily be associated with improved long-term outcomes or no beneficial effect for children with steroid-/cyclophosphamide-/cyclosporinedependent/resistant nephrotic syndrome (Table 1). While rituximab is increasingly used in treating idiopathic steroid-resistant nephrotic syndrome in children, MMF may be an effective and safe maintenance therapy as an additional immunosuppressant among children with persistent steroid-resistant nephrotic syndrome [55].

Cyclosporine A (CsA) (Table 1) has been effective in treating and preventing frequent relapse of MCD with $C R$ rates up to $80 \%$ [44]. CsA is relatively safe to use in developing chronic cyclosporine nephrotoxicity with or without other immunosuppressive agents [56]. Steroid-resistant patients benefit from CsA while steroid-sensitive patients have an alternative besides prednisolone. The combination of CsA and prednisolone can reduce the initial dosage of prednisolone, hence shortening the time to remission and easily maintaining it. This combination protocol indicated the effectiveness and usefulness and could potentially be a future treatment strategy for frequent-relapse nephrotic syndrome [57]. The most crucial drawback of CsA (Table 1) could be the high relapse rate after withdrawal of the medication.

Tacrolimus (Table 1) with high remission rates of up to $91 \%$ achieved in 2 years has been reported. Moreover, remission rates of up to $100 \%$ were reported in a few case series $[29,58,59]$. Tacrolimus could be a promising second option for cyclosporine in steroid-resistant and steroid-dependent nephrotic syndrome due to its high remission rate [60]. Tacrolimus was suggested to be used as a combined therapy [61] with the first reported case showing that sirolimus successfully resulted in remission in minimal change nephropathy [62].

Dexamethasone could recover podocyte injury by regulating podocytes' structure because it acts as the critical cytoskeletal protein anchoring the focal adhesion and slit diaphragm proteins that are responsible for podocyte attachment to both the underlying glomerular basement membrane and adjacent podocytes [63]. Table 1 shows the 
TABLE 1: Commonly used medication in minimal change disease.

\begin{tabular}{lc}
\hline Treatments options & Description/usefulness \\
\hline & (i) Standardized treatment for \\
MCD in children and adults [1, & $11]$ \\
$\begin{array}{l}\text { Prednisolone } \\
\text { (glucocorticoids) }\end{array}$ & $\begin{array}{l}\text { (ii) Responsiveness of infant } \\
\text { towards prednisolone as } \\
\text { diagnosis of MCD without } \\
\text { biopsy }\end{array}$
\end{tabular}

(i) Useful in children but lack Levamisole (synthetic molecular explanation $[37,106]$ imidazole)
(ii) Cheap, least toxic, and could prevent relapse [39]

Drawback/limitation

(i) Dreadful adverse effect [34]

(ii) Often used in combination with other medications

(iii) Exact mode of action is unknown [2]

(iv) Not useful for steroid-resistant MCD patients

(v) Not designed for MCD patients

(i) Availability issue [106]

(ii) Extremely high relapse followed by discontinued treatment [106]
Target molecule/cell

(i) Glucocorticoid receptor,

T helper subtype 2 (Th2)

cytokines such as interleukin-4 and interleukin-13 [34]

(i) Modulates type 1 and type 2 immune response by enhancing interleukin-18 [107]

(ii) Glucocorticoid receptor's signaling as critical target of levamisole's action [37]

(i) Unknown in MCD [110]

(ii) Effective at reducing antibody production by B cell; T cells could be affected by the expression of aldehyde dehydrogenase [109] (ii) Higher rate of cumulative sustained remission compared with cyclosporine [108] (i) Various severe side effects reported including bone marrow suppression, bladder toxicity, gonadal toxicity, malignancy, hemorrhagic cystitis, gastrointestinal disturbances, alopecia, and infection $[1,109]$ (i) Unidentified
Chlorambucil
(alkylating agent)

Mycophenolate

Mofetil

(immunosuppressive

agent) (i) Second option after cyclophosphamide

(i) Less side effects than cyclosporine [49-51]

(ii) Important effects on treatment course together with rituximab [111] (i) Greater toxicity without any improvement [1]

(i) More effective in lupus nephritis instead of MCD [53]

(ii) No beneficial result for steroid-, cyclophosphamide-, and cyclosporineresistant patients [112] (i) Inosine monophosphate dehydrogenase (IMPDH) [51] (i) Optimal dose is unknown [2], but medium dose is safe for developing nephrotoxicity [56]

(i) Effective in treating and preventing relapse in steroidunresponsive children [113]

Cyclosporine A (calcineurin inhibitor)

(ii) Effective strategy to combine with prednisolone [57] (iii) The first option as immunosuppressant for treating children with refractory nephrotic syndrome [83] (ii) Long-term outcome is unknown and may not beneficial to steroiddependent nephrotic syndrome patients [114]

(iii) High relapse rate right after medication withdrawal

(iv) Hypertension as the most common adverse effect followed by increase of creatinine levels, hyperkalemia, gingival hyperplasia, and hypertrichosis [110, (i) Nuclear factor of activated $\mathrm{T}$ cell (NFAT) [116]

(ii) Phosphorylates synaptopodin in podocyte (stabilization by binding to 14-3-3 site) [83] 115]

(i) Promising second option of steroid and cyclosporine resistance with high remission rate [60]

(ii) Combined therapy with sirolimus was effective [62]

Tacrolimus (calcineurin inhibitor) (iii) Tacrolimus is 10 to 100 times more potent than cyclosporine in its immunosuppressive effects [117]

(iv) Lower relapse rate and cosmetic side effects compared to cyclosporine $[115,118]$ (i) Worsen and new onset of hypertension reported [59]

(ii) New onset of diabetes mellitus, infection was reported [59]

(iii) Increased risk of diabetes mellitus [115] (i) Inhibit $\mathrm{T}$ lymphocyte by binding with FKBP-12, calcium, calmodulin, and calcineurin [117] 
TABle 1: Continued.

\begin{tabular}{|c|c|c|c|}
\hline Treatments options & Description/usefulness & Drawback/limitation & Target molecule/cell \\
\hline $\begin{array}{l}\text { Dexamethasone } \\
\text { (glucocorticoid) }\end{array}$ & $\begin{array}{c}\text { (i) Stabilize actin filament } \\
\text { (reduce podocyte effacement) } \\
\text { [119] } \\
\text { (ii) Partially inhibit CD80 [64] } \\
\text { (iii) Protect podocyte from } \\
\text { apoptosis [120] }\end{array}$ & $\begin{array}{l}\text { (i) Hypertension and hypokalemia were } \\
\text { reported with intravenous } \\
\text { dexamethasone administration [46] } \\
\text { (ii) Worsened proteinuria condition } \\
\text { was reported [121] }\end{array}$ & $\begin{array}{l}\text { (i) RhoA activities [122] } \\
\text { (ii) Apoptosis mechanism protein such } \\
\text { as tumor suppressor protein p53, bcl-2 } \\
\text { family protein, caspase-3, and } \\
\text { apoptosis-inducing factor (AIF) [120] } \\
\text { (iii) Upregulated nephrin and tubulin- } \\
\alpha \text {, downregulated vascular endothelial } \\
\text { growth factor [28] } \\
\text { (iv) Interleukin- } 6 \text { and interleukin-8 } \\
\text { suppressed by dexamethasone [28] }\end{array}$ \\
\hline
\end{tabular}

(i) Immediate response for 11year nephrotic syndrome patient to achieve remission (free from proteinuria) [123]

(ii) Prevention of actin cytoskeleton disruption [66]

Rituximab (antibody) (iii) Achieved remission from proteinuria was reported in many case series [111, 124]

(iv) Safe and effective to induce and remain remission; serious side effects were uncommon [74, 125] (i) Common adverse effects such as fever, chills, nausea; urticaria, orthostatic hypotension, and bronchospasm are rare; most of the adverse effects were during the first infusion [126]

(ii) Not recommended in the guideline of therapy due to serious side effects [67]; $45 \%$ of cases reported different types of mild or transient adverse effects in a case series [124] (i) Type 1 chimeric monoclonal antibody CD20 [66, 75]

(ii) Relapse always associated with CD19 in FSGS patients (contradicts with other patients' CD19 levels and lack of established evidence) [124]

(iii) $\mathrm{T}$ helper cell 17 (Th17) and interleukin-17 [127, 128] (i) Effective alternative of

Ofatumumab (antibody) rituximab [75], fully humanized (ii) Dramatic positive response reported [76] (i) Various toxicities were reported [75]

(i) Effective outcome of

Abatacept (fusion protein) (i) Increased risk of bacterial infection

[129] rheumatoid arthritis repurpose

medication on MCD patients

was reported $[7,23,78]$ (i) Different epitope of CD20 than rituximab [75] potential mechanism of why dexamethasone could increase the stability of the actin filaments hence reducing podocyte effacement by partially blocking the activation of Toll-like receptor 3 that induces the expression of CD80 and phenotypic change via an NF- $\kappa \mathrm{B}$-dependent mechanism [64]. The knockdown of CD80 protected against actin reorganization and reduced synaptopodin expression [64].

Rituximab (Table 1) is an antibody against CD20, which upon administration will severely deplete B cells [65]. A study reported that overexpression of sphingomyelin phosphodiesterase acid-like 3b (SMPDL-3b) or treatment with rituximab could prevent disruption of the actin cytoskeleton and podocyte apoptosis [66]. An effective case series in Table 1 affirmed the role of rituximab in proteinuria condition; however, studies by Guigonis et al. (2008) were focusing on FSGS patients instead of MCD patients. Adverse effects were observed in ten cases by Guigonis et al. (2008) and also reported in Bagga's review that rituximab has serious adverse effects, in which it was only used if other agents fail to show the result [67]. In another study, it was suggested that the antiproteinuric effect of rituximab might be independent of B cell depletion [66]. Moreover, it was reported that rituximab could be useful for predicting relapse in patients with nephrotic syndrome [68] and sustained CR of steroid- and cyclophosphamide-resistant MCD patients with a single course of rituximab therapy was reported as well [69]. Nevertheless, among many other medications compared with rituximab with regard to the long-term remission, only rituximab was reported to successfully have long-term remission of MCD [70]. T helper cell 17 in Table 1 was reported to associate with reduced inflammation.

Nonetheless, it was reported that the annual relapse rate had been reduced by rituximab [71]. Additionally, rituximab could change the course of severe relapsing steroiddependent nephrotic syndrome; evidence showed in a case studied [72] in which the authors speculated that rituximab could either directly affect or change the responsiveness to cyclosporine, but the attempt to reduce or withdraw cyclosporine should be monitored. With such shreds of evidence, anti-CD20 antibodies may be a promising therapy [73]. Controversial reports regarding the effectiveness against FSGS and MCD shall be investigated further with all researchers' efforts to report the actual value of rituximab and firm conclusion [74].

It was surprising that due to the rituximab resistance of patients of nephrotic syndrome, ofatumumab (Table 1) was given as treatment of multidrug resistance of chronic lymphocytic leukemia in a case study of a 19-year-old girl with 
TABLE 2: Less frequently used medication in minimal change disease.

\begin{tabular}{|c|c|c|c|}
\hline Treatments & Description/usefulness & Drawback/limitation & Target molecule/cell \\
\hline $\begin{array}{l}\text { Mizoribine } \\
\text { (imidazole) }\end{array}$ & $\begin{array}{l}\text { (i) Reduced relapse rate and prolonged } \\
\text { remission were reported [130] } \\
\text { (ii) Provides protective effects against CsA } \\
\text { nephrotoxicity [131] } \\
\text { (iii) Replacement immunosuppressive agent of } \\
\text { azathioprine due to lower toxicity for } \\
\text { childhood nephrotic syndrome and steroid- } \\
\text { resistant nephrotic syndrome [80] }\end{array}$ & $\begin{array}{l}\text { (i) Not widely used due to low } \\
\text { efficacy [80] } \\
\text { (ii) Not recommended for use in } \\
\text { children [132] }\end{array}$ & $\begin{array}{c}\text { (i) Inhibition of DNA } \\
\text { synthesis, specifically to } \\
\text { lymphocyte proliferation [80] }\end{array}$ \\
\hline
\end{tabular}

(i) Not effective to prevent relapse

in nephrotic syndrome children

$$
\text { [133] }
$$

Azathioprine

(imidazole)

(i) Complete remission was reported but only in 1 patient out of 20 [30] (ii) Ineffective result had been noted [134]

(iii) Not well documented [135]

(iv) Not recommended for use in children [132] (i) Inhibition of DNA

synthesis, specifically to

lymphocyte [136] (i) Extremely limited evidence and studies, result only based on 1 (i) Disappearance of proteinuria reported in frequent relapse nephrotic syndrome patient [87]

Pefloxacin

(i) Reduce the frequency of relapse in patients [88]

Mechlorethamine (alkylating agent)

(i) Suggested as potential approach [2]

Sirolimus (mammalian target of rapamycin (mTOR) inhibitor)

(ii) Been used together with cyclosporine in 2 patients but the result is unclear [100]

(iii) More commonly used in kidney transplant patients

$$
\text { patient [86] }
$$

(ii) Toxicity towards joints, ankle, knee, and neck was reported [87]

(i) Extremely limited evidence and studies, result only based on less than 5 patients [86]

(i) Anemia as commonly noted side effect [137], the most common side effect is hyperlipidemia [62]

(ii) Studies showed sirolimus itself might have caused proteinuria

$[138]$
(iii) Most studies were FSGS

(i) Unclear [85], lack of studies in nephrotic syndrome

(i) Unclear, lack of studies in nephrotic syndrome related instead of MCD (i) Inhibit proliferation of $\mathrm{T}$ lymphocytes, fibroblast, endothelial, mesangial, and smooth muscle cells [138]

$$
\text { Galiximab (antibody) }
$$

Basiliximab
(antibody)
(antibody)

(i) Effective single dose to achieve complete remission and remission was reported $[70,139]$

(i) Potential approach

(i) Subgroup that is TNF associated could be partially benefited [141] (i) Never tested or used in kidneyrelated disease

(i) CD80 [82]

(i) Addition of basiliximab to treatment did not improve clinical outcome [140]

(i) Interleukin-2 [89, 139]

(ii) CD25 [70]

(i) Studies conducted but no available result [15]

(ii) Not suggested further in resistant FSGS [141]

(i) Tumor necrosis factor- $\alpha$ $(\mathrm{TNF}-\alpha)$

(iii) Studies in FSGS patients, lack of MCD focused

(i) Proteinuria reduction and kidney function preservation were reported [141]

Galactose

(ii) Remission of nephrotic syndrome in multiple immunosuppressant-resistant patient was reported [142]

(i) Evidences of reduced proteinuria,

Thiazolidinediones (synthetic peroxisome) microalbuminuria, podocyte injury, vascular injury, inflammation, and fibrosis were reported [110]

(ii) Podocyte protective feature was noted, (i) Studies conducted but no available result [15]

(ii) Studies in FSGS patients, lack of MCD focused (i) High affinity with FSGS permeability factor [142]

(i) Most studies focus on diabetic nephropathy and nondiabetic glomerulosclerosis, lack of studies in MCD patients (i) Activation of the glucocorticoid receptor [110]

(ii) Decrease transforming growth factor production [143] 
TABLe 2: Continued.

\begin{tabular}{lccc}
\hline Treatments & Description/usefulness & Drawback/limitation & Target molecule/cell \\
\hline & $\begin{array}{c}\text { could possibly be the potential therapy due to } \\
\text { the similar response of glucocorticoids }[110]\end{array}$ & & \\
\hline
\end{tabular}

(i) Potentially worsen kidney's

health and proteinuria [145]

(ii) Lesser data than sirolimus [146] inhibitor)

(i) Cytoskeleton stabilizing effect reported for the first time in 2013 [144]

(ii) Lack of studies, especially in MCD (iii) Mostly renal transplant focused instead of MCD (i) Inhibition of T cell proliferation

(ii) RhoA signaling [144]

\begin{tabular}{llll}
\hline Fresolimumab & (i) Partially achieved remission and reduce & (i) FSGS patient studies, not MCD & $\begin{array}{c}\text { (i) Transforming growth } \\
\text { factor-beta [147] }\end{array}$ \\
\hline Sparsentan & (i) Reduced proteinuria in FSGS [147] & & $\begin{array}{c}\text { (i) Endothelin type A and } \\
\text { angiotensin II type 1 receptor } \\
\text { [147] }\end{array}$
\end{tabular}

a 6-year history of steroid-resistant nephrotic syndrome [75]. The therapy of ofatumumab had given a shocking response in the patient's renal status, in which proteinuria improved after only the first dose of ofatumumab [76]. Ofatumumab could be an effective treatment for steroid-resistant nephrotic syndrome, but more confirmation studies should be conducted for this observation. Ofatumumab was reported to enhance its efficacy in combination with chemotherapy and biological agents [75]. The response of steroid-resistant nephrotic syndrome towards rituximab and ofatumumab suggests a robust logical approach towards CD80 investigation and the potential effectiveness of anti-CD80 specifically against minimal change nephrotic syndrome.

Abatacept (cytotoxic T lymphocyte-associated antigen 4immunoglobulin fusion protein (CTLA-4-Ig)) is a costimulatory inhibitor that targets B7-1 (CD80) [23]. There was evidence that abatacept (CTLA-4-immunoglobulin fusion protein) may both directly and indirectly support the fact that MCD patients could be impaired with Tregs by inhibiting the pathogenesis of rheumatoid arthritis at several levels via selective modulation of CD80/CD86 costimulatory molecules of MCD [7, 77]. A case report presented that abatacept was believed to have a fundamental role in maintaining disease remission and supported the value of CD80 in relapsing MCD patients [78]. In the case report by Isom et al., the longest successful usage of abatacept to treat a relapsing steroid-dependent MCD patient was reported. With that, the MCD patient had a successful reduced usage of both tacrolimus and prednisone.

Mizoribine (Table 2) was reported to significantly reduce the relapse rate and prolong the remission period of nephrotic syndrome [79]. Mizoribine is more commonly used than azathioprine as an immunosuppressive drug [80]. Azathioprine (Table 2) was reported as a cheaper alternative second to cyclophosphamide, and the efficacy might be restricted [81]. The studies on azathioprine were limited and did not prove with convincing results, but it should be reserved for future investigation.

Galiximab is an antibody against CD80 [82], but it was never tested with renal disease patients. Nonetheless, it could also be an option to further investigate its mechanism towards MCD patients. Galiximab is an anti-CD80 monoclo- nal antibody, besides abatacept, a CD80 targeting protein; nonetheless, abatacept is not the antibody of CD80 [83]. It was reported that galiximab had been used as a treatment for hematologic malignancy, such as relapsed nonHodgkin's lymphoma $[82,84]$. However, there is not much information regarding the effectiveness of galiximab, and certainly, it has never been used for any renal disease. Therefore, the research interest for galiximab remains for targeting podocyte and proteinuria.

Pefloxacin (Table 2) had antiproteinuric effect in a small group of patients which was reported, but later on it is not widely used or reported [85-87]. Mechlorethamine had been reported in the medication histories of some patients in a study against rituximab [86] as well as the effect of reducing relapse frequency in patients [88]. Limited information is available about the purpose of this medication in MCD; usually, it was used as an alternative of alkylating agents besides CHL and CYC.

Basiliximab (Table 2), an anti-interleukin-2 (IL-2), was reported to show effectiveness in some minimal change nephrotic syndrome patients [89]. The surprisingly significant effect of basiliximab shown in Table 2 provided good insight of the antibody's role in MCD. Although basiliximab's effectiveness was reported in a case study, it was insufficient to provide scientific logic towards the result because the patients also suffer from several disease- and treatmentassociated complications such as indirect inguinal hernias, cataracts, and bacterial infections. Therefore, the mechanisms of basiliximab might vary, and further investigation should be performed.

Figure 1 summarizes the commonly used medication in MCD. There were other potential treatment approaches reported such as the use of sirolimus, everolimus, adalimumab, fresolimumab, sparsentan, galactose, and thiazolidinediones summarized in Table 2. However, these approaches extremely lack strong evidence and are weakly associated with MCD. Most of the studies were not MCD focused. Nonetheless, their role in proteinuria condition should not be overlooked in this multifactorial disease. Multiple sclerosis-approved medication FTY720 which is an immunosuppressive agent for CD80 had been suggested as potential 


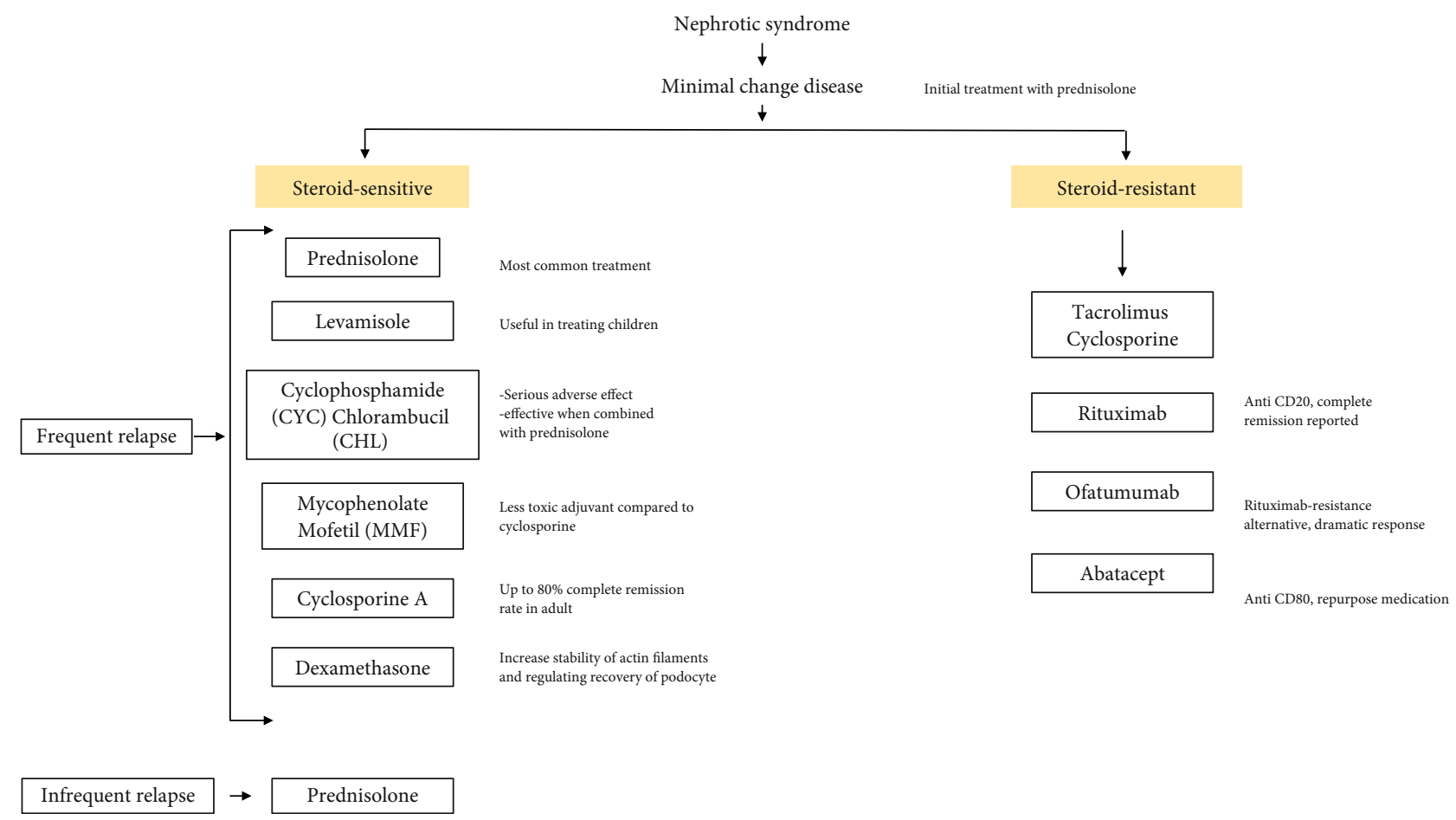

Figure 1

TABLE 3: Studies of CD80 in minimal change disease that are support or against in both animals and humans.

\begin{tabular}{|c|c|c|c|}
\hline Animal studies & Stance on CD80 & Human studies & Stance on CD80 \\
\hline Reiser et al., 2004 [24] & Support & Garin et al., 2009 [22] & Support \\
\hline Shi et al., 2011 [149] & Support & Garin et al., 2010 [100] & Support \\
\hline Ishimoto et al., 2013 [102] & Support & Ishimoto et al., 2013 [101] & Support \\
\hline Novelli et al., 2016 [20] & Against & Yu et al., 2013 [23] & Support \\
\hline Rivard et al., 2018 [150] & Support & Cara-Fuentes et al., 2014 [26] & Support \\
\hline \multirow{12}{*}{ Khullar et al., 2018 [95] } & \multirow{12}{*}{ Support } & Novelli et al., 2016 [20] & Against \\
\hline & & Mishra et al., 2017 [151] & Support \\
\hline & & Liao et al., 2017 [94] & Support \\
\hline & & Minamikawa et al., 2018 [152] & Against \\
\hline & & Zhao et al., 2018 [153] & Support \\
\hline & & Ling et al., 2018 [8] & Support \\
\hline & & Ahmed et al., 2018 [154] & Support \\
\hline & & Bhatia et al., 2018 [155] & Support \\
\hline & & Isom et al., 2019 [78] & Support \\
\hline & & Cara-Fuentes et al., 2020 [156] & Support \\
\hline & & Chen et al., 2020 [157] & Support \\
\hline & & Gonzalez et al., 2020 [158] & Support \\
\hline
\end{tabular}

treatment of podocyte injury [83]; however, no further studies had been done in MCD patients.

\section{Discussion}

The recent finding suggested that the therapeutic targets for glucocorticosteroids, cyclosporine, and rituximab could be the molecules expressed by podocytes in MCD [15]. Novel therapeutic agents directed against these molecules may assist in the stabilization and reconstruction of podocytes in MCD. For instance, the suppression of CD80 expression on podocytes could be the therapeutic interest in MCD, FSGS, and glomerular disease [7]. Moreover, the actin cytoskeleton could be a therapeutic target as disorganization in the actin 
TABLE 4: CD80 in human studies' summary.

\begin{tabular}{|c|c|c|c|c|}
\hline Studies & Type of studies & Subject number & Main finding & Conclusion \\
\hline $\begin{array}{l}\text { Garin et al., } \\
2009[22]\end{array}$ & Clinical studies & $\begin{array}{l}\text { MCD patients: } n=19 \\
\text { Control subjects: } n=9 \\
\text { FSGS patients: } n=4\end{array}$ & $\begin{array}{l}\text { Urinary CD80 was significantly } \\
\text { higher in relapse MCD patients } \\
\text { than MCD in remission. }\end{array}$ & $\begin{array}{l}\text { Urinary CD80 is elevated in } \\
\text { idiopathic MCD and relevant to } \\
\text { diagnosis and prognosis. }\end{array}$ \\
\hline $\begin{array}{l}\text { Garin et al., } \\
2010[100]\end{array}$ & Clinical studies & $\begin{array}{l}\text { MCD patients: } n=17 \\
\text { FSGS patients: } n=22\end{array}$ & $\begin{array}{l}\text { CD80 is not elevated in } \\
\text { FSGS patients. }\end{array}$ & $\begin{array}{l}\text { CD80 may be a useful marker, } \\
\text { supported hypothesis that MCD } \\
\text { and FSGS were two different } \\
\text { diseases. }\end{array}$ \\
\hline $\begin{array}{l}\text { Ishimoto et al., } \\
2013 \text { [101] }\end{array}$ & $\begin{array}{l}\text { Basic science } \\
\text { studies }\end{array}$ & $\begin{array}{l}\text { Human podocyte } \\
\text { cell line }\end{array}$ & $\begin{array}{l}\text { An impaired CTLA4 response, } \\
\text { the rapid upregulation of CTLA4 in } \\
\text { glomeruli could be responsible for } \\
\text { the transient CD } 80 \text { expression. }\end{array}$ & $\begin{array}{l}\text { CD80 production in podocytes } \\
\text { with transient proteinuria; } \\
\text { CD80 was relevant in the } \\
\text { pathogenesis } \\
\text { of proteinuria in MCD. }\end{array}$ \\
\hline $\begin{array}{l}\text { Yu et al., } \\
2013[23]\end{array}$ & $\begin{array}{l}\text { Clinical and basic } \\
\text { science studies }\end{array}$ & FSGS patients: $n=5$ & $\begin{array}{c}\text { CD80 could be a useful biomarker } \\
\text { in the treatment of some } \\
\text { glomerulopathies. }\end{array}$ & $\begin{array}{l}\text { Abatacept induced complete or } \\
\text { partial remission of proteinuria } \\
\text { in patients. }\end{array}$ \\
\hline $\begin{array}{l}\text { Cara-Fuentes } \\
\text { et al., } 2014 \text { [26] }\end{array}$ & Clinical studies & $\begin{array}{c}\text { MCD: } \\
\text { In relapse: } n=20 \\
\text { In remission: } n=21 \\
\text { FSGS patients: } n=26\end{array}$ & $\begin{array}{l}\text { FSGS patients have significant } \\
\text { higher level of suPAR than } \\
\text { relapse-MCD patients which } \\
\text { showed } \\
\text { correlation with proteinuria. }\end{array}$ & $\begin{array}{l}\text { Urinary CD } 80 \text { is elevated in MCD } \\
\text { patients compared with FSGS } \\
\text { patients. }\end{array}$ \\
\hline $\begin{array}{l}\text { Novelli et al., } \\
2016[20]\end{array}$ & $\begin{array}{l}\text { Clinical and basic } \\
\text { science studies }\end{array}$ & $\begin{array}{l}\text { MCD patients: } n=15 \\
\text { FSGS patients: } n=16 \\
\text { Male Balb/c mice for } \\
\text { basic science studies }\end{array}$ & $\begin{array}{l}\text { The therapeutic effect of abatacept } \\
\text { might not be because of } \\
\text { podocyte CD } 80 .\end{array}$ & $\begin{array}{l}\text { Podocyte CD } 80 \text { was not observed in } \\
\text { mice or patients of MCD and FSGS. }\end{array}$ \\
\hline $\begin{array}{l}\text { Mishra et al., } \\
2017 \text { [151] }\end{array}$ & Clinical studies & $\begin{array}{l}\text { Nephrotic syndrome } \\
\text { patients: } n=70 \\
\text { Healthy controls: } \\
\quad n=23\end{array}$ & $\begin{array}{l}\text { MCD patients had higher median } \\
\text { in expressing potential biomarkers } \\
\text { than FSGS patients but no } \\
\text { significant difference. }\end{array}$ & $\begin{array}{l}\text { Urinary creatine/CD } 80 \text { could be } \\
\text { useful biomarkers in steroid- } \\
\text { sensitive } \\
\text { nephrotic syndrome in relapse. }\end{array}$ \\
\hline $\begin{array}{l}\text { Liao et al., } \\
2017 \text { [94] }\end{array}$ & Clinical studies & $\begin{array}{c}\text { Nephrotic syndrome } \\
\text { patients: } n=128 \\
\text { Healthy controls: } \\
n=25\end{array}$ & $\begin{array}{l}\text { Higher urinary CD80 in recurrent } \\
\text { phase steroid-sensitive nephrotic } \\
\text { syndrome than healthy control } \\
\text { or remission patients. }\end{array}$ & $\begin{array}{l}\text { Urinary CD80 was strongly } \\
\text { associated } \\
\text { with relapse nephrotic syndrome } \\
\text { but } \\
\text { cannot be used as frequency of } \\
\text { relapse prediction. }\end{array}$ \\
\hline $\begin{array}{l}\text { Minamikawa } \\
\text { et al., } 2018 \text { [152] }\end{array}$ & Clinical & $\begin{array}{l}\text { MCD patients: } n=31 \\
\text { FSGS: } n=9 \\
\text { Healthy controls: } \\
n=30\end{array}$ & $\begin{array}{l}\text { Urinary CD80 was present in all } \\
\text { active chronic kidney disease. } \\
\text { Urinary CD80 was correlated with } \\
\text { the urinary protein levels. }\end{array}$ & $\begin{array}{l}\text { Urinary CD } 80 \text { was an unreliable } \\
\text { biomarker to differentiate relapse } \\
\text { MCD and FSGS. }\end{array}$ \\
\hline $\begin{array}{l}\text { Zhao et al., } \\
2018 \text { [153] }\end{array}$ & Clinical & MCD patients: $n=55$ & $\begin{array}{l}\text { CTLA4 absent or in minimum } \\
\text { amount could distinguish steroid- } \\
\text { sensitive MCD patients from } \\
\text { steroid- } \\
\text { resistant MCD patients. }\end{array}$ & $\begin{array}{l}\text { Glucocorticoid was useful to result } \\
\text { complete remission only in MCD } \\
\text { patients, with strong CD80 level } \\
\text { and minimum level of CTLA4. }\end{array}$ \\
\hline $\begin{array}{l}\text { Ling et al., } \\
2018 \text { [8] }\end{array}$ & Clinical & $\begin{array}{l}\text { Nephrotic syndrome } \\
\text { patients: } n=64\end{array}$ & $\begin{array}{l}\text { Urinary CD } 80 \text { level could affect } \\
\text { the response towards the initial } \\
\text { treatment of steroid. High urinary } \\
\text { CD } 80 \text { level reacted } 100 \% \text { at the } \\
\text { initial steroid treatment. }\end{array}$ & $\begin{array}{l}\text { Urinary CD } 80 \text { could predict the } \\
\text { progression and remission of MCD } \\
\text { in children, while also able to } \\
\text { identify high-risk patients at } \\
\text { an early stage. }\end{array}$ \\
\hline $\begin{array}{l}\text { Ahmed et al., } \\
2018[154]\end{array}$ & Clinical & $\begin{array}{c}\text { MCD patients: } n=21 \\
\text { FSGS patients: } n=9 \\
\text { Other } \\
\text { glomerulopathies: } \\
n=6 \\
\text { Healthy controls: } \\
n=40\end{array}$ & $\begin{array}{l}\text { Urinary CD } 80 \text { in MCD was } \\
\text { significantly higher than FSGS } \\
\text { and other glomerulopathies. }\end{array}$ & $\begin{array}{l}\text { Urinary CD } 80 \text { was significantly } \\
\text { higher in MCD child patients. }\end{array}$ \\
\hline
\end{tabular}


TABLE 4: Continued.

\begin{tabular}{|c|c|c|c|c|}
\hline Studies & Type of studies & Subject number & Main finding & Conclusion \\
\hline $\begin{array}{l}\text { Bhatia et al., } \\
2018 \text { [155] }\end{array}$ & Clinical & $\begin{array}{l}\text { Steroid-dependent } \\
\text { nephrotic syndrome } \\
\text { patients: } n=18\end{array}$ & $\begin{array}{l}\text { The first study to report the effect of } \\
\text { rituximab on urinary CD80 } \\
\text { excretion. }\end{array}$ & $\begin{array}{l}\text { Reduced urinary CD80 was } \\
\text { observed } \\
\text { after rituximab therapy. }\end{array}$ \\
\hline $\begin{array}{l}\text { Isom et al., } \\
2019 \text { [78] }\end{array}$ & Clinical case study & MCD patients: $n=1$ & $\begin{array}{l}\text { The longest successful abatacept } \\
\text { treatment that has ever been } \\
\text { reported; } 6 \text { years of follow up, } \\
\text { abatacept tremendously changed } \\
\text { the pattern of relapse. }\end{array}$ & $\begin{array}{c}\text { Strongly encourage the investigation } \\
\text { of urinary CD } 80 \text { as therapeutic and } \\
\text { potential treatment target. }\end{array}$ \\
\hline $\begin{array}{l}\text { Cara-Fuentes } \\
\text { et al., } \\
2020[156]\end{array}$ & $\begin{array}{l}\text { Clinical and basic } \\
\text { science studies }\end{array}$ & $\begin{array}{l}\text { MCD patients: } n=9 \\
\text { FSGS patients: } n=11\end{array}$ & $\begin{array}{l}\text { Relapse MCD patients had less } \\
\text { CTLA4+ in glomeruli which } \\
\text { caused the imbalance ratio of } \\
\text { CD80/CTLA4 locally. There was a } \\
\text { link between CD80 and endothelial } \\
\text { cell activation. A second hit to the } \\
\text { glomerulus could result in more } \\
\text { significant podocytes injury } \\
\text { and proteinuria. }\end{array}$ & $\begin{array}{l}\text { Both podocytes and endothelial } \\
\text { cells could be the potential } \\
\text { sources of CD80 in human } \\
\text { and animal model. }\end{array}$ \\
\hline $\begin{array}{l}\text { Chen et al., } \\
2020 \text { [157] }\end{array}$ & Clinical & $\begin{array}{l}\text { MCD patients in } \\
\text { relapse: } n=10 \\
\text { MCD patients in } \\
\text { remission: } n=9 \\
\text { Healthy controls: } n=9\end{array}$ & $\begin{array}{l}\text { No correlation between urinary } \\
\text { CD80 and proteinuria in adult } \\
\text { onset MCD. Urinary CD80 was not } \\
\text { a reflection of proteinuria. }\end{array}$ & $\begin{array}{c}\text { Imbalance level of Th1/TH2/TH17 } \\
\text { and elevated CD } 80 \text { could be the } \\
\text { pathogenesis of developing adult } \\
\text { onset MCD. }\end{array}$ \\
\hline $\begin{array}{l}\text { Gonzalez et al., } \\
2020 \text { [158] }\end{array}$ & Clinical & $\begin{array}{c}\text { MCD patients: } n=53 \\
\text { FSGS patients: } n=43 \\
\text { Healthy controls: } \\
n=34\end{array}$ & $\begin{array}{l}\text { Urinary CD } 80 \text { could serve as } \\
\text { predictive marker for the potential } \\
\text { responsiveness towards specific } \\
\text { immunosuppressive agents. }\end{array}$ & $\begin{array}{l}\text { Urinary CD80 could discriminate } \\
\text { MCD from other nephrotic } \\
\text { syndrome diseases. }\end{array}$ \\
\hline
\end{tabular}

cytoskeleton architecture caused podocyte effacement (injury of podocyte foot process), which might represent the underlying molecular pattern for the morphogenetic transformation, and there was a study demonstrating that stabilizing the actin cytoskeleton is of therapeutic value [90].

A combination of treatments shown in Figure 1 shall be considered in this multifactorial disease (MCD) instead of monotreatment. The therapeutic target of MCD could be more than one at the same time. Therefore, it is challenging to pinpoint an absolute effective treatment against MCD. A multilayer of treatments shall be considered after screening prominent targeted markers shown in Tables 1 and 2. A combination treatment of antibodies and glucocorticoids should be investigated for its efficiency for relapse patients since a monotreatment approach of either glucocorticoids or inhibitor medication such as abatacept did not show a promising result. Combination treatment with prednisolone such as rituximab with prednisolone [91], mycophenolate with a low dose of prednisolone [92], and cyclosporine with prednisolone [93] had been studied but not CD80. Thus, a combination of CD80 antibodies with a low dose of prednisolone could be an excellent potential approach. The combination of prednisolone and cyclosporine treatment did show changes in overall response and should be an essential option of treatment [93]. The combination of mycophenolate with a low dose of prednisolone is also helping with better tolerability and fewer adverse effects [92]. Perhaps, the approach of a combination of medication could replace sole use of prednisolone.
The increase of urinary CD80 in SSNS relapse patients [94] shows the positive result with glucocorticoids at the beginning. However, the relapse happened with higher urinary CD80 level detected, giving reasonable speculation that CD80 should be targeted individually instead of giving generic immunosuppressive drugs because if the immunosuppressive drug is valid the relapse shall not happen. Hence, a specific antibody targeting MCD-caused CD80 expression should be developed instead of using a repurpose drug of rheumatoid arthritis (abatacept). Abatacept (B7-1 blocker) should not be rushed to be introduced as treatment until ongoing research about CD80 provides more information [20]. The treatment of the B7-1 blocker as a potential treatment remains controversial because it is not consistent with other studies [17].

Despite the evidence of some studies indicating that CD80 may not be valuable as a therapeutic target, studies by Reiser et al. and Khullar et al. showed that the induction of CD80 in podocytes might drive proteinuria and podocyte dysfunction [24, 95]. On the other hand, the researcher in Table 3 also found remarkable improvement from case studies of proteinuria in a child with recurrent MCD and a young adult gentleman with relapsing condition; both individuals were treated with abatacept $[78,96]$. Evidence from Isom et al.'s studies is strongly encouraging that CD80 should remain as an attractive diagnostic and prognostic biomarker. Table 3 puts together a series of recent studies of CD80 in MCD from animal and human studies. Table 4 summarizes the human studies of CD80; there were limited studies 
against the value of CD80. Nonetheless, due to the nature of the MCD being multifactorial, there are at least 76 different causes and associations which have been reported with regard to minimal change disease $[97,98]$; keeping an open mind towards frequent-relapsing MCD patients that show increased level of CD80 as a therapeutic target will be beneficial than shutting the door of the possibility of its role in the pathogenesis of MCD. Many studies prove CD80 values as positive in MCD until Novelli et al. (2016) and Minamikawa et al. (2018) reported the negative finding of CD80 in MCD and FSGS patients which had created a polarization effect on the researcher. Nevertheless, let us be reminded again that MCD is a multifactorial disease; it could both be right (positive outcome and negative outcome); the focus should remain on the condition and environment that leads to the negative finding of it to understand the pathway better instead of weighting yes or no of the role of CD80. A negative finding of CD80 in MCD and FSGS patients only sparks the curiosity of the researcher to investigate more in-depth of its relevant pathogenesis backtracking to the origin of the disease, whether it is primary-caused MCD or secondarycaused MCD.

Studies that debate over CD80 as a nonreliable biomarker are understandable. In contrast, studies that show CD80 is associated with MCD are well evidenced, because there are far too many reasons and potential association to cause podocyte effacement, which manifests as minimal change disease. The reason could range from toxicity, immunology, charge distortion, signaling pathway activation, and genetic modification. Each of these categories manifests different mechanism and different pathogenesis related to MCD most of the time known as idiopathic MCD. Therefore, despite the ambiguous speculation of the role of CD80 in MCD, the importance of the role of CD80 in MCD indeed has been reported [22, 26, 64, 99-102]; hence, whether CD80 should be or should not be a therapeutic target indeed remains a colossal interest for the researcher to investigate further [103]. There might be a close link between CD80 and angiopoietin-like 4 (Angptl4) which is also a key player in the induction of proteinuria, but the relationship between Angptl4 and CD80 is not yet determined [104] because in a mouse model of MCD that was injured with LPS both the expressions of Angptl4 in adipose tissue [105] and CD80 on podocytes [24] increased.

\section{Conclusion}

Various fields have been explored, but the current clinical practice towards MCD patients still relies heavily on immunosuppressive medication. Podocyte indeed sparks a vast research interest, but again, it does not change the clinical practice towards MCD patients. The challenges of MCD always lie on unknown therapeutic target. The multifactorial nature of the disease should be treated with the screening of specific biomarkers before any treatments. Based on the positive outcome of the various medications in this review paper, we support the idea that elevated specific biomarkers could be targeted more effectively rather than general immunosuppressive medication. A personalized treatment starting from the screening of specific biomarkers shall be practiced from new emerging evidence in the studies of MCD. Future research shall focus on various in-depth biomarker patterns; thus, customization of MCD treatment plans could work. The positive study outcomes of CD20 (rituximab) medication in Table 1, also the inhibitor of CD80 (abatacept), trigger the interest and strong likelihood of investigating specific antibodies of CD80 for therapeutic effects. CD80 therapeutic (antibody) aspect was never clinically or thoroughly investigated; most of the research about CD80 was still debating the involvement of CD80 in MCD. The role of CD80 could be subtle or specific in certain conditions such as frequent relapse or the injury mechanism; again, MCD is a multifactorial disease. Hence, an effective target-specific antibody for CD80 that could reduce the effacement of podocyte's foot process and cease the proteinuria condition in a frequentrelapse MCD patient will ultimately prove the value of CD80. Yet, such studies are rare.

\section{Additional Points}

Review Criteria. The review was based on the search of Google Scholar, PubMed, Web of Science, and Scopus with a combination of search terms including the following: "minimal change disease", "treatment options", "CD80", "nephrotic syndrome", "frequent-lapse", and "proteinuria". No date or language restriction was set during the search.

\section{Conflicts of Interest}

The authors declared no competing interests in this review.

\section{Authors' Contributions}

Yoong Mond Teh contributed to drafting the article and revising it critically for important content, and Siti Aisyah Mualif reviewed the draft thoroughly, provided insightful comments, and approved the final version to be submitted. The authors contributed equally to all aspects of the manuscripts.

\section{Acknowledgments}

We are thankful that this work is supported by the Research University Grant Scheme by Universiti Teknologi Malaysia (UTM): Tier 2 grant (Q.J130000.2651.18J09) and UTM Fundamental Research grant (Q.J130000.2551.21H36).

\section{References}

[1] S. B. Bansal, "Minimal change disease," Clinical Queries: Nephrology, vol. 3, no. 2-4, pp. 114-123, 2014.

[2] A. A. Eddy and J. M. Symons, "Nephrotic syndrome in childhood," The lancet, vol. 362, no. 9384, pp. 629-639, 2003.

[3] A. Al Talhi, K. Al Saran, E. T. Osman, A. Al Shatri, M. Osman, and K. Mirza, "A randomized study on a 3month versus a 7 -month prednisolone regimen for the initial episode of childhood idiopathic nephrotic syndrome at a large Saudi center," International Journal of Pediatrics and Adolescent Medicine, vol. 5, no. 1, pp. 18-23, 2018. 
[4] R. Shalhoub, "Pathogenesis of lipoid nephrosis: a disorder of T-cell function,” The Lancet, vol. 304, no. 7880, pp. 556-560, 1974.

[5] V. Elie, M. Fakhoury, G. Deschênes, and E. Jacqz-Aigrain, "Physiopathology of idiopathic nephrotic syndrome: lessons from glucocorticoids and epigenetic perspectives," Pediatric nephrology, vol. 27, no. 8, pp. 1249-1256, 2012.

[6] A. Koyama, M. Fujisaki, M. Kobayashi, M. Igarashi, and M. Narita, "A glomerular permeability factor produced by human T cell hybridomas," Kidney international, vol. 40, no. 3, pp. 453-460, 1991.

[7] K. Kaneko, S. Tsuji, T. Kimata, T. Kitao, S. Yamanouchi, and S. Kato, "Pathogenesis of childhood idiopathic nephrotic syndrome: a paradigm shift from T-cells to podocytes," World Journal of Pediatrics, vol. 11, no. 1, pp. 21-28, 2015.

[8] C. Ling, X. Liu, Y. Shen et al., "Urinary CD80 excretion is a predictor of good outcome in children with primary nephrotic syndrome," Pediatric Nephrology, vol. 33, 2018.

[9] C. C. Szeto, F. M. Lai, K. M. Chow et al., "Long-term outcome of biopsy-proven minimal change nephropathy in Chinese adults," American Journal of Kidney Diseases, vol. 65, no. 5, pp. 710-718, 2015.

[10] V. D. D'Agati, F. J. Kaskel, and R. J. Falk, "Focal segmental glomerulosclerosis," New England Journal of Medicine, vol. 365, no. 25, pp. 2398-2411, 2011.

[11] P. Nachman and J. Jenette, "Primary glomerular disease," The kidney, 987-1000, 2008.

[12] H. Trachtman, J. Hogan, and J. Radhakrishnan, Chapter 17 minimal change disease, 2014.

[13] V. Gupta and J. Reiser, "Stop that podocyte!," American Journal of Physiology. Renal Physiology, vol. 312, no. 2, pp. F373F374, 2017.

[14] P. Mundel, "Podocyte biology and response to injury," Journal of the American Society of Nephrology, vol. 13, no. 12, pp. 3005-3015, 2002.

[15] J. Muller-Deile and M. Schiffer, "Podocyte directed therapy of nephrotic syndrome-can we bring the inside out?," Pediatric Nephrology, vol. 31, no. 3, pp. 393-405, 2016.

[16] J. G. van den Berg, M. A. van den Bergh Weerman, K. J. Assmann, J. J. Weening, and S. Florquin, "Podocyte foot process effacement is not correlated with the level of proteinuria in human glomerulopathies," Kidney International, vol. 66, no. 5, pp. 1901-1906, 2004.

[17] G. Cara-Fuentes, M. A. Lanaspa, G. E. Garcia, M. Banks, E. H. Garin, and R. J. Johnson, "Urinary CD80: a biomarker for a favorable response to corticosteroids in minimal change disease," Pediatric Nephrology, vol. 33, no. 7, pp. 1101-1103, 2018.

[18] K. Wing, Y. Onishi, P. Prieto-Martin et al., "CTLA-4 control over Foxp3+ regulatory T cell function," Science, vol. 322, no. 5899, pp. 271-275, 2008.

[19] C. Araya, L. Diaz, C. Wasserfall et al., "T regulatory cell function in idiopathic minimal lesion nephrotic syndrome," Pediatric Nephrology, vol. 24, no. 9, pp. 1691-1698, 2009.

[20] R. Novelli, E. Gagliardini, B. Ruggiero, A. Benigni, and G. Remuzzi, "Any value of podocyte B7-1 as a biomarker in human MCD and FSGS?," American Journal of Physiology. Renal Physiology, vol. 310, no. 5, pp. F335-F341, 2016.

[21] Y. A. P. H-K, W. CHEUNG, B. MURUGASU, S. I. M. S-K, S. E. A. H. C-C, and S. C. JORDAN, "Th1 and Th2 cytokine mRNA profiles in childhood nephrotic syndrome: evidence for increased IL-13 mRNA expression in relapse," Journal of the American Society of Nephrology, vol. 10, no. 3, pp. 529537, 1999.

[22] E. H. Garin, L. N. Diaz, W. Mu et al., "Urinary CD80 excretion increases in idiopathic minimal-change disease," Journal of the American Society of Nephrology, vol. 20, no. 2, pp. 260266, 2009.

[23] C. C. Yu, A. Fornoni, A. Weins et al., "Abatacept in B7-1positive proteinuric kidney disease," The New England Journal of Medicine, vol. 369, no. 25, pp. 2416-2423, 2013.

[24] J. Reiser, G. von Gersdorff, M. Loos et al., "Induction of B7-1 in podocytes is associated with nephrotic syndrome," The Journal of Clinical Investigation, vol. 113, no. 10, pp. 13901397, 2004.

[25] D. J. Salant, "Podocyte expression of B7-1/CD80: is it a reliable biomarker for the treatment of proteinuric kidney diseases with abatacept?," Journal of the American Society of Nephrology, vol. 27, no. 4, pp. 963-965, 2016.

[26] G. Cara-Fuentes, C. Wei, A. Segarra et al., "CD80 and suPAR in patients with minimal change disease and focal segmental glomerulosclerosis: diagnostic and pathogenic significance," Pediatric Nephrology, vol. 29, no. 8, pp. 13631371, 2014.

[27] M. A. Lal, K. W. Young, and U. Andag, "Targeting the podocyte to treat glomerular kidney disease," Drug Discovery Today, vol. 20, no. 10, pp. 1228-1234, 2015.

[28] C.-Y. Xing, M. Saleem, R. Coward, L. Ni, I. Witherden, and P. Mathieson, "Direct effects of dexamethasone on human podocytes," Kidney international, vol. 70, no. 6, pp. 10381045, 2006.

[29] M. Waldman, R. J. Crew, A. Valeri et al., "Adult minimalchange disease: clinical characteristics, treatment, and outcomes," Clinical Journal of the American Society of Nephrology, vol. 2, no. 3, pp. 445-453, 2007.

[30] K. C. Tse, M. F. Lam, P. S. Yip et al., "Idiopathic minimal change nephrotic syndrome in older adults: steroid responsiveness and pattern of relapses," Nephrology Dialysis Transplantation, vol. 18, no. 7, pp. 1316-1320, 2003.

[31] C. L. Chembo, M. R. Marshall, L. C. Williams et al., "Longterm outcomes for primary glomerulonephritis: New Zealand Glomerulonephritis Study," Nephrology, vol. 20, no. 12, pp. 899-907, 2015.

[32] S. W. Lee, M. Y. Yu, S. H. Baek et al., "Glomerular immune deposits are predictive of poor long-term outcome in patients with adult biopsy-proven minimal change disease: a cohort study in Korea," PloS one, vol. 11, no. 1, 2016.

[33] B. K. Ekka, A. Bagga, and R. Srivastava, "Single-versus divided-dose prednisolone therapy for relapses of nephrotic syndrome," Pediatric nephrology, vol. 11, no. 5, pp. 597599, 1997.

[34] A. M. Schijvens, R. ter Heine, S. N. De Wildt, and M. F. Schreuder, "Pharmacology and pharmacogenetics of prednisone and prednisolone in patients with nephrotic syndrome," Pediatric Nephrology, vol. 34, no. 3, pp. 389-403, 2019.

[35] A. S. Abeyagunawardena, M. J. Dillon, L. Rees, W. van't Hoff, and R. S. Trompeter, "The use of steroid-sparing agents in steroid-sensitive nephrotic syndrome," Pediatric nephrology, vol. 18, no. 9, pp. 919-924, 2003.

[36] M. J. Kemper and T. J. Neuhaus, "Levamisole in relapsing steroid-sensitive nephrotic syndrome: where do we stand?" Kidney International, vol. 93, no. 2, pp. 310-313, 2018. 
[37] L. Jiang, I. Dasgupta, A. Hurcombe Jenny, F. Colyer Heather, W. Mathieson Peter, and G. I. Welsh, "Levamisole in steroidsensitive nephrotic syndrome: usefulness in adult patients and laboratory insights into mechanisms of action via direct action on the kidney podocyte," Clinical Science, vol. 128, no. 12, pp. 883-893, 2015.

[38] P. W. Mathieson, "The podocyte as a target for therapies-new and old," Nature Reviews Nephrology, vol. 8, no. 1, pp. 52-56, 2012.

[39] F. Veltkamp, D. H. Khan, C. Reefman et al., "Prevention of relapses with levamisole as adjuvant therapy in children with a first episode of idiopathic nephrotic syndrome: study protocol for a double blind, randomised placebo-controlled trial (the LEARNS study)," BMJ Open, vol. 9, no. 8, article e027011, 2019.

[40] M. P. Gruppen, A. H. Bouts, M. C. Jansen-van der Weide et al., "A randomized clinical trial indicates that levamisole increases the time to relapse in children with steroidsensitive idiopathic nephrotic syndrome," Kidney International, vol. 93, no. 2, pp. 510-518, 2018.

[41] E. M. Hodson, N. S. Willis, and J. C. Craig, "Non-corticosteroid treatment for nephrotic syndrome in children," Cochrane Database of Systematic Reviews, vol. 1, 2008.

[42] K. Latta, C. von Schnakenburg, and J. H. Ehrich, "A metaanalysis of cytotoxic treatment for frequently relapsing nephrotic syndrome in children," Pediatric nephrology, vol. 16, no. 3, pp. 271-282, 2001.

[43] N. Ueda, K. Kuno, and S. Ito, "Eight and 12 week courses of cyclophosphamide in nephrotic syndrome," Archives of disease in childhood, vol. 65, no. 10, pp. 1147-1150, 1990.

[44] S. M. Korbet and W. L. Whittier, "Management of adult minimal change disease," Clinical Journal of the American Society of Nephrology, vol. 14, no. 6, pp. 911-913, 2019.

[45] D. C. Cattran, J. Feehally, H. T. Cook et al., "Kidney disease: improving global outcomes (KDIGO) glomerulonephritis work group. KDIGO clinical practice guideline for glomerulonephritis," Kidney International Supplements, vol. 2, no. 2, pp. 139-274, 2012.

[46] M. Mantan, C. S. Sriram, P. Hari, A. Dinda, and A. Bagga, "Efficacy of intravenous pulse cyclophosphamide treatment versus combination of intravenous dexamethasone and oral cyclophosphamide treatment in steroid-resistant nephrotic syndrome," Pediatric Nephrology, vol. 23, no. 9, pp. 14951502, 2008.

[47] M. S-k, L. K-y, C. Y. Wong, G. M. Tong, W. P-n, and A. K. Wong, "Treatment with cyclophosphamide in elderly-onset nephrotic syndrome," Nephron Clinical Practice, vol. 101, no. 1, pp. c25-c32, 2005.

[48] F. Nolasco, J. S. Cameron, E. Heywood, J. Hicks, C. Ogg, and D. G. Williams, "Adult-onset minimal change nephrotic syndrome: a long-term follow-up," Kidney international, vol. 29, no. 6, pp. 1215-1223, 1986.

[49] E. M. Dorresteijn, J. E. Kist-van Holthe, E. N. Levtchenko, J. Nauta, W. C. Hop, and A. J. van der Heijden, "Mycophenolate mofetil versus cyclosporine for remission maintenance in nephrotic syndrome," Pediatric Nephrology, vol. 23, no. 11, pp. 2013-2020, 2008.

[50] S. Fujinaga, Y. Ohtomo, D. Hirano et al., "Mycophenolate mofetil therapy for childhood-onset steroid dependent nephrotic syndrome after long-term cyclosporine: extended experience in a single center," Clinical nephrology, vol. 72, no. 4, pp. 268-273, 2009.
[51] V. Sepe, C. Libetta, M. Giuliano, G. Adamo, and C. A. Dal, "Mycophenolate mofetil in primary glomerulopathies," Kidney international, vol. 73, no. 2, pp. 154-162, 2008.

[52] Y.-P. Siu, M. Tong, K. Leung, T.-H. Kwan, and T.-C. Au, "The use of enteric-coated mycophenolate sodium in the treatment of relapsing and steroid-dependent minimal change disease," Journal of nephrology, vol. 21, no. 1, pp. 127-131, 2008.

[53] C. Kitiyakara, V. Ophascharoensuk, S. Changsirikulchai et al., "Treatment of lupus nephritis and primary glomerulonephritis with enteric-coated mycophenolate sodium," Clinical nephrology, vol. 69, no. 2, pp. 90-101, 2008.

[54] N. Dimkovic, D. Jovanovic, Z. Kovacevic et al., "Mycophenolate mofetil in high-risk patients with primary glomerulonephritis: results of a 1-year prospective study," Nephron Clinical Practice, vol. 111, no. 3, pp. c189-c196, 2009.

[55] B. Basu, T. K. S. Mahapatra, and N. Mondal, "Mycophenolate mofetil following rituximab in children with steroid-resistant nephrotic syndrome," Pediatrics, vol. 136, no. 1, article e132, 2015.

[56] Y. Kuroyanagi, Y. Gotoh, K. Kasahara et al., "Effectiveness and nephrotoxicity of a 2-year medium dose of cyclosporine in pediatric patients with steroid-dependent nephrotic syndrome: determination of the need for follow-up kidney biopsy," Clinical and Experimental Nephrology, vol. 22, no. 2, pp. 413-419, 2018.

[57] I. Kondo, Y. Arai, A. Hamada et al., "A case of frequently relapsing minimal-change nephrotic syndrome with steroid-induced psychiatric syndrome treated by low-dose, short-term steroid therapy in combination with cyclosporine," Case Reports in Nephrology and Dialysis, vol. 10, no. 1, pp. 1-8, 2020.

[58] T. Westhoff, S. Schmidt, W. Zidek, J. Beige, and M. Van der Giet, "Tacrolimus in steroid-resistant and steroiddependent nephrotic syndrome," Clinical nephrology, vol. 65 , no. $6,2006$.

[59] X. Li, H. Li, H. Ye et al., “Tacrolimus therapy in adults with steroid-and cyclophosphamide-resistant nephrotic syndrome and normal or mildly reduced GFR," American journal of kidney diseases, vol. 54, no. 1, pp. 51-58, 2009.

[60] N. R. Medjeral-Thomas, C. Lawrence, M. Condon et al., "Randomized, controlled trial of tacrolimus and prednisolone monotherapy for adults with de novo minimal change disease," Clinical Journal of the American Society of Nephrology, vol. 15, no. 2, pp. 209-218, 2020.

[61] H. L. Guo, J. Xu, J. Y. Sun et al., "Tacrolimus treatment in childhood refractory nephrotic syndrome: a retrospective study on efficacy, therapeutic drug monitoring, and contributing factors to variable blood tacrolimus levels," International Immunopharmacology, vol. 81, p. 106290, 2020.

[62] P. Patel, S. Pal, C. Ashley, P. Sweny, and A. Burns, "Combination therapy with sirolimus (rapamycin) and tacrolimus (FK506) in treatment of refractory minimal change nephropathy, a clinical case report," Nephrology Dialysis Transplantation, vol. 20, no. 5, pp. 985-987, 2005.

[63] D. Kerjaschki, "Caught flat-footed: podocyte damage and the molecular bases of focal glomerulosclerosis," The Journal of clinical investigation, vol. 108, no. 11, pp. 1583-1587, 2001.

[64] M. Shimada, T. Ishimoto, P. Y. Lee et al., "Toll-like receptor 3 ligands induce CD80 expression in human podocytes via an NF- $\kappa$ B-dependent pathway," Nephrology Dialysis Transplantation, vol. 27, no. 1, pp. 81-89, 2012. 
[65] A. Jamin, L. Berthelot, A. Couderc et al., "Autoantibodies against podocytic UCHL1 are associated with idiopathic nephrotic syndrome relapses and induce proteinuria in mice," Journal of Autoimmunity, vol. 89, pp. 149-161, 2018.

[66] A. Fornoni, J. Sageshima, C. Wei et al., "Rituximab targets podocytes in recurrent focal segmental glomerulosclerosis," Science translational medicine, vol. 3, no. 85, p. 85ra46, 2011.

[67] A. Bagga, "Therapies for glomerular diseases in children," Annals of the National Academy of Medical Sciences (India), vol. 54, no. 1, pp. 43-53, 2018.

[68] M. Colucci, R. Carsetti, S. Cascioli et al., "B cell reconstitution after rituximab treatment in idiopathic nephrotic syndrome," Journal of the American Society of Nephrology, vol. 27, no. 6, pp. 1811-1822, 2016.

[69] J. Janardan, K. Ooi, and S. Menahem, "Sustained complete remission of steroid- and cyclophosphamide-resistant minimal-change disease with a single course of rituximab therapy," Clinical Kidney Journal, vol. 7, no. 3, pp. 293-295, 2014.

[70] H. François, E. Daugas, A. Bensman, and P. Ronco, "Unexpected efficacy of rituximab in multirelapsing minimal change nephrotic syndrome in the adult: first case report and pathophysiological considerations," American Journal of Kidney Diseases, vol. 49, no. 1, pp. 158-161, 2007.

[71] A. Kronbichler, J. Kerschbaum, G. Fernandez-Fresnedo et al., "Rituximab treatment for relapsing minimal change disease and focal segmental glomerulosclerosis: a systematic review," American journal of nephrology, vol. 39, no. 4, pp. 322-330, 2014.

[72] K. Benz, J. Dotsch, W. Rascher, and D. Stachel, "Change of the course of steroid-dependent nephrotic syndrome after rituximab therapy," Pediatric Nephrology, vol. 19, no. 7, pp. 794-797, 2004.

[73] H. Peters, N. van de Kar, and J. Wetzels, Rituximab in minimal change nephropathy and focal segmental glomerulosclerosis: report of four cases and review of the literature, 2008.

[74] A. Kronbichler, P. Gauckler, and A. Bruchfeld, "Rituximab in minimal change disease and focal segmental glomerulosclerosis," Nephrology Dialysis Transplantation, 2019.

[75] B. D. Cheson, "Ofatumumab, a novel anti-CD20 monoclonal antibody for the treatment of B-cell malignancies," Journal of Clinical Oncology, vol. 28, no. 21, pp. 3525-3530, 2010.

[76] B. Basu, "Ofatumumab for rituximab-resistant nephrotic syndrome," New England Journal of Medicine, vol. 370, no. 13, pp. 1268-1270, 2014.

[77] M. Cutolo and S. G. Nadler, "Advances in CTLA-4-Ig-mediated modulation of inflammatory cell and immune response activation in rheumatoid arthritis," Autoimmunity reviews, vol. 12, no. 7, pp. 758-767, 2013.

[78] R. Isom, S. Shoor, J. Higgins, G. Cara-Fuentes, and R. J. Johnson, "Abatacept in steroid-dependent minimal change disease and CD80-uria," Kidney international reports, vol. 4, no. 9, pp. 1349-1353, 2019.

[79] K. Yoshioka, Y. Ohashi, T. Sakai et al., "A multicenter trial of mizoribine compared with placebo in children with frequently relapsing nephrotic syndrome," Kidney international, vol. 58, no. 1, pp. 317-324, 2000.

[80] Y. Kawasaki, "Mizoribine: a new approach in the treatment of renal disease," Clinical and Developmental Immunology, vol. 2009, 2009.
[81] H. Tanaka, N. Onodera, and S. Waga, "Long-term azathioprine therapy in two children with steroid-dependent minimal-change nephrotic syndrome," The Tohoku journal of experimental medicine, vol. 187, no. 3, pp. 273-278, 1999.

[82] S. Bhat and M. S. Czuczman, "Galiximab: a review," Expert opinion on biological therapy, vol. 10, no. 3, pp. 451-458, 2010.

[83] T.-H. Yoo and A. Fornoni, "Nonimmunologic targets of immunosuppressive agents in podocytes," Kidney research and clinical practice, vol. 34, no. 2, pp. 69-75, 2015.

[84] S. Vinjamaram, M. S. Czuczman, and F. J. Hernandez-Ilizaliturri, "The use of galiximab in non-Hodgkin lymphoma," Clinical Lymphoma and Myeloma, vol. 8, no. 5, pp. 277282, 2008.

[85] T. Zima, V. Tesar, I. Rychlík et al., "The effect of pefloxacin on nephrotic syndrome in experimental adriamycin nephropathy," Casopis lekaru ceskych, vol. 134, no. 20, pp. 658-660, 1995.

[86] H. Munyentwali, K. Bouachi, V. Audard et al., "Rituximab is an efficient and safe treatment in adults with steroiddependent minimal change disease," Kidney International, vol. 83, no. 3, pp. 511-516, 2013.

[87] B. Diouf, M. Djoneidi, S. Diallo, T. Diop, and O. Bao, "Pefloxacin in the treatment of childhood nephrotic syndrome: a case report," Saudi Journal of Kidney Diseases and Transplantation, vol. 7, no. 1, pp. 31-33, 1996.

[88] R. J. Glassock, "Therapy of relapsing minimal-change disease in adults: a new approach?," Kidney International, vol. 83, no. 3, pp. 343-345, 2013.

[89] S. H. Kim, S. J. Park, K. H. Han et al., "Pathogenesis of minimal change nephrotic syndrome: an immunological concept," Korean Journal of Pediatrics, vol. 59, no. 5, pp. 205211, 2016.

[90] C. Schell and T. B. Huber, "The evolving complexity of the podocyte cytoskeleton," Journal of the American Society of Nephrology, vol. 28, no. 11, pp. 3166-3174, 2017.

[91] A.-L. Sellier-Leclerc, M.-A. Macher, C. Loirat et al., "Rituximab efficiency in children with steroid-dependent nephrotic syndrome," Pediatric Nephrology, vol. 25, no. 6, pp. 1109$1115,2010$.

[92] M. K. Ma, D. Y. Yap, C. L. Li et al., "Low-dose corticosteroid and mycophenolate for primary treatment of minimal change disease," QJM: An International Journal of Medicine, vol. 113, no. 6, pp. 399-403, 2020.

[93] A. Eguchi, T. Takei, T. Yoshida, K. Tsuchiya, and K. Nitta, "Combined cyclosporine and prednisolone therapy in adult patients with the first relapse of minimal-change nephrotic syndrome," Nephrology Dialysis Transplantation, vol. 25, no. 1, pp. 124-129, 2010.

[94] J. Liao, X.-C. Wu, Q. Cheng et al., "Predictability of urinary CD80 in the relapse of primary nephrotic syndrome," BioMed Research International, vol. 2017, Article ID 9429314, 6 pages, 2017.

[95] B. Khullar, R. Balyan, N. Oswal et al., "Interaction of CD80 with Neph1: a potential mechanism of podocyte injury," Clinical and Experimental Nephrology, vol. 22, no. 3, pp. 508-516, 2018.

[96] E. H. Garin, J. Reiser, G. Cara-Fuentes et al., "Case series: CTLA4-IgG1 therapy in minimal change disease and focal segmental glomerulosclerosis," Pediatric Nephrology, vol. 30, no. 3, pp. 469-477, 2015. 
[97] R. J. Glassock, "Secondary minimal change disease," Nephrology Dialysis Transplantation, vol. 18, suppl_6, pp. vi52-vi58, 2003.

[98] G. V. Prasad, L. Vincent, R. Hamilton, and K. Lim, "Minimal change disease in association with fire coral (Millepora species) exposure," American Journal of Kidney Diseases, vol. 47, no. 1, pp. e15-e16, 2006.

[99] M. Shimada, C. Araya, C. Rivard, T. Ishimoto, R. J. Johnson, and E. H. Garin, "Minimal change disease: a "two-hit" podocyte immune disorder?," Pediatric Nephrology, vol. 26, no. 4, pp. 645-649, 2011.

[100] E. H. Garin, W. Mu, J. M. Arthur et al., "Urinary CD80 is elevated in minimal change disease but not in focal segmental glomerulosclerosis," Kidney International, vol. 78, no. 3, pp. 296-302, 2010.

[101] T. Ishimoto, G. Cara-Fuentes, H. Wang et al., "Serum from minimal change patients in relapse increases CD80 expression in cultured podocytes," Pediatric Nephrology, vol. 28, no. 9, pp. 1803-1812, 2013.

[102] T. Ishimoto, M. Shimada, G. Gabriela et al., "Toll-like receptor 3 ligand, polyIC, induces proteinuria and glomerular CD80, and increases urinary CD80 in mice," Nephrology Dialysis Transplantation, vol. 28, no. 6, pp. 1439-1446, 2013.

[103] J. Reiser and M. M. Altintas, "Podocytes," F1000Research, vol. 5, 2016.

[104] S. S. Chugh, L. C. Clement, and C. Macé, "New insights into human minimal change disease: lessons from animal models," American Journal of Kidney Diseases, vol. 59, no. 2, pp. 284-292, 2012.

[105] B. Lu, A. Moser, J. K. Shigenaga, C. Grunfeld, and K. R. Feingold, "The acute phase response stimulates the expression of angiopoietin like protein 4," Biochemical and biophysical research communications, vol. 391, no. 4, pp. 1737-1741, 2010.

[106] J. Oh and M. J. Kemper, "Second-line options for refractory steroid-sensitive and -resistant nephrotic syndrome," Expert Review of Clinical Pharmacology, vol. 3, no. 4, pp. 527-537, 2010.

[107] C. Szeto, K. M. Gillespie, and P. W. Mathieson, "Levamisole induces interleukin-18 and shifts type 1/type 2 cytokine balance," Immunology, vol. 100, no. 2, pp. 217-224, 2000.

[108] V. Sümegi, I. Haszon, C. Bereczki, F. Papp, and S. Túri, "Long-term follow-up after cyclophosphamide and cyclosporine-a therapy in steroid-dependent and -resistant nephrotic syndrome," Pediatric Nephrology, vol. 23, no. 7, pp. 1085-1092, 2008.

[109] C. Ponticelli, R. Escoli, and G. Moroni, "Does cyclophosphamide still play a role in glomerular diseases?," Autoimmunity Reviews, vol. 17, no. 10, pp. 1022-1027, 2018.

[110] L. A. Greenbaum, R. Benndorf, and W. E. Smoyer, "Childhood nephrotic syndrome-current and future therapies," Nature Reviews Nephrology, vol. 8, no. 8, pp. 445-458, 2012.

[111] E. Y. Chan, H. Webb, E. Yu et al., "Both the rituximab dose and maintenance immunosuppression in steroid-dependent/frequently-relapsing nephrotic syndrome have important effects on outcomes," Kidney International, vol. 97, no. 2, pp. 393-401, 2020.

[112] V. Baglio, G. Pecci, C. Gangemi, G. Barresi, S. Morabito, and A. Pierucci, "Failure of mycophenolate mofetil therapy in primary refractory nephrotic syndrome," Journal of nephrology, vol. 19, no. 6, pp. 819-824, 2006.
[113] G. Malakasioti, D. Iancu, and K. Tullus, "Calcineurin inhibitors in nephrotic syndrome secondary to podocyte gene mutations: a systematic review," Pediatric Nephrology, vol. 12, 2020.

[114] S. Fujinaga, D. Hirano, T. Nishino, C. Umeda, Y. Watanabe, and M. Nakagawa, "Long-term outcome of Japanese children with complicated minimal change nephrotic syndrome treated with mycophenolate mofetil after cyclosporine," Pediatric Nephrology, vol. 34, no. 11, pp. 2417-2421, 2019.

[115] S. Choudhry, A. Bagga, P. Hari, S. Sharma, M. Kalaivani, and A. Dinda, "Efficacy and safety of tacrolimus versus cyclosporine in children with steroid-resistant nephrotic syndrome: a randomized controlled trial," American journal of kidney diseases, vol. 53, no. 5, pp. 760-769, 2009.

[116] C. Faul, M. Donnelly, S. Merscher-Gomez et al., "The actin cytoskeleton of kidney podocytes is a direct target of the antiproteinuric effect of cyclosporine A," Nature medicine, vol. 14, no. 9, pp. 931-938, 2008.

[117] J. C. Mejia, A. Basu, and R. Shapiro, "Chapter 17 - calcineurin inhibitors," in Kidney Transplantation-Principles and Practice (Seventh Edition), P. J. Morris and S. J. Knechtle, Eds., pp. 231-249, Content Repository Only!, Philadelphia (PA), 2014.

[118] W. Wang, Y. Xia, J. Mao et al., "Treatment of tacrolimus or cyclosporine A in children with idiopathic nephrotic syndrome," Pediatric Nephrology, vol. 27, no. 11, pp. 20732079, 2012.

[119] F. Castellino, J. Heuser, S. Marchetti, B. Bruno, and A. Luini, "Glucocorticoid stabilization of actin filaments: a possible mechanism for inhibition of corticotropin release," Proceedings of the National Academy of Sciences, vol. 89, no. 9, pp. 3775-3779, 1992.

[120] T. Wada, J. W. Pippin, C. B. Marshall, S. V. Griffin, and S. J. Shankland, "Dexamethasone prevents podocyte apoptosis induced by puromycin aminonucleoside: role of p53 and Bcl-2-related family proteins," Journal of the American Society of Nephrology, vol. 16, no. 9, p. 2615, 2005.

[121] S. J. Mudge, K. Paizis, R. B. Auwardt, V. Levidiotis, S. A. Fraser, and D. A. Power, "Corticosteroids worsen proteinuria and increase intraglomerular signaling by NF-kB in a model of membranous glomerulonephritis," Nephron Experimental Nephrology, vol. 116, no. 2, pp. e23-e31, 2010.

[122] S. Ashraf, H. Kudo, J. Rao et al., "Mutations in six nephrosis genes delineate a pathogenic pathway amenable to treatment," Nature Communications, vol. 9, no. 1, p. 1960, 2018.

[123] G. C. Smith, "Is there a role for rituximab in the treatment of idiopathic childhood nephrotic syndrome?," Pediatric Nephrology, vol. 22, no. 6, pp. 893-898, 2007.

[124] V. Guigonis, A. Dallocchio, V. Baudouin et al., "Rituximab treatment for severe steroid-or cyclosporine-dependent nephrotic syndrome: a multicentric series of 22 cases," Pediatric Nephrology, vol. 23, no. 8, p. 1269, 2008.

[125] P. Hansrivijit, W. Cheungpasitporn, C. Thongprayoon, and N. Ghahramani, "Rituximab therapy for focal segmental glomerulosclerosis and minimal change disease in adults: a systematic review and meta-analysis," Bmc Nephrology, vol. 21, no. 1, p. 11, 2020.

[126] U. Winkler, M. Jensen, O. Manzke, H. Schulz, V. Diehl, and A. Engert, "Cytokine-release syndrome in patients with Bcell chronic lymphocytic leukemia and high lymphocyte counts after treatment with an anti-CD20 monoclonal 
antibody (rituximab, IDEC-C2B8)," Blood, vol. 94, no. 7, pp. 2217-2224, 1999.

[127] A. Alunno, F. Carubbi, O. Bistoni et al., "Interleukin (IL)-17producing pathogenic $\mathrm{T}$ lymphocytes co-express CD20 and are depleted by rituximab in primary Sjögren's syndrome: a pilot study," Clinical \& Experimental Immunology, vol. 184, no. 3, pp. 284-292, 2016.

[128] S. J. Park and J. I. Shin, "Another beneficial effect of rituximab on refractory ANCA-associated vasculitis: the role of interleukin-17 suppression?," Scandinavian Journal of Immunology, vol. 77, no. 3, pp. 221-221, 2013.

[129] L. Moreland, G. Bate, and P. Kirkpatrick, "Abatacept," Nature Reviews Drug Discovery, vol. 5, no. 3, pp. 185-186, 2006.

[130] M. Fujieda, M. Ishihara, T. Morita et al., "Effect of single-dose oral mizoribine pulse therapy twice per week for frequently relapsing steroid-dependent nephrotic syndrome," Clinical Nephrology, vol. 78, no. 1, pp. 40-46, 2012.

[131] A. Endo, T. Someya, M. Nakagawa et al., "Synergistic protective effects of mizoribine and angiotensin II receptor blockade on cyclosporine A nephropathy in rats," Pediatric Research, vol. 75, no. 1, pp. 38-44, 2014.

[132] P. Ravani, E. Bertelli, S. Gill, and G. M. Ghiggeri, "Clinical trials in minimal change disease," Nephrology Dialysis Transplantation, vol. 32, suppl_1, pp. i7-i13, 2017.

[133] A. M. Durkan, E. M. Hodson, N. S. Willis, and J. C. Craig, "Immunosuppressive agents in childhood nephrotic syndrome: a meta-analysis of randomized controlled trials," Kidney international, vol. 59, no. 5, pp. 1919-1927, 2001.

[134] C. J. Day, P. Cockwell, G. W. Lipkin, C. O. Savage, A. J. Howie, and D. Adu, "Mycophenolate mofetil in the treatment of resistant idiopathic nephrotic syndrome," Nephrology Dialysis Transplantation, vol. 17, no. 11, pp. 2011-2013, 2002.

[135] J. Hogan and J. Radhakrishnan, "The treatment of minimal change disease in adults," Journal of the American Society of Nephrology, vol. 24, no. 5, pp. 702-711, 2013.

[136] A. Anstey and J. T. Lear, "Azathioprine," BioDrugs, vol. 9, no. 1, pp. 33-47, 1998.

[137] J. J. Augustine, T. C. Knauss, J. A. Schulak, K. A. Bodziak, C. Siegel, and D. E. Hricik, "Comparative effects of sirolimus and mycophenolate mofetil on erythropoiesis in kidney transplant patients," American Journal of Transplantation, vol. 4, no. 12, pp. 2001-2006, 2004.

[138] F. C. Fervenza, P. M. Fitzpatrick, J. Mertz et al., “Acute rapamycin nephrotoxicity in native kidneys of patients with chronic glomerulopathies," Nephrology Dialysis Transplantation, vol. 19, no. 5, pp. 1288-1292, 2004.

[139] S.-S. Park, W.-H. Hahn, S.-D. Kim, and B.-S. Cho, "Remission of refractory minimal change nephrotic syndrome after basiliximab therapy," Pediatric Nephrology, vol. 24, no. 7, pp. 1403-1407, 2009.

[140] R. Grenda, A. Watson, K. Vondrak et al., "A prospective, randomized, multicenter trial of tacrolimus-based therapy with or without basiliximab in pediatric renal transplantation," American Journal of Transplantation, vol. 6, no. 7, pp. 1666-1672, 2006.

[141] H. Trachtman, S. Vento, E. Herreshoff et al., "Efficacy of galactose and adalimumab in patients with resistant focal segmental glomerulosclerosis: report of the font clinical trial group," BMC Nephrology, vol. 16, no. 1, p. 111, 2015.
[142] E. De Smet, J.-P. Rioux, H. Ammann, C. Déziel, and S. Quérin, "FSGS permeability factor-associated nephrotic syndrome: remission after oral galactose therapy," Nephrology Dialysis Transplantation, vol. 24, no. 9, pp. 2938-2940, 2009.

[143] T. Kawai, T. Masaki, S. Doi et al., "PPAR- $\gamma$ agonist attenuates renal interstitial fibrosis and inflammation through reduction of TGF- $\beta$," Laboratory Investigation, vol. 89, no. 1, pp. 47-58, 2009.

[144] S. Jeruschke, A. K. Büscher, J. Oh et al., "Protective effects of the mTOR inhibitor everolimus on cytoskeletal injury in human podocytes are mediated by RhoA signaling," PLoS One, vol. 8, no. 2, p. 14, 2013.

[145] R. Vogelbacher, S. Wittmann, A. Braun, C. Daniel, and C. Hugo, "The mTOR inhibitor everolimus induces proteinuria and renal deterioration in the remnant kidney model in the rat," Transplantation, vol. 84, no. 11, pp. 1492-1499, 2007.

[146] E. Letavernier and C. Legendre, "mToR inhibitors-induced proteinuria: mechanisms, significance, and management," Transplantation Reviews, vol. 22, no. 2, pp. 125-130, 2008.

[147] J. M. Lee, A. Kronbichler, J. I. Shin, and J. Oh, "Current understandings in treating children with steroid-resistant nephrotic syndrome," Pediatric Nephrology, 2020.

[148] H. Trachtman, P. Nelson, S. Adler et al., "DUET: a phase 2 study evaluating the efficacy and safety of sparsentan in patients with FSGS," Journal of the American Society of Nephrology, vol. 29, no. 11, pp. 2745-2754, 2018.

[149] Q. Shi, Z. Y. Gao, F. Xie et al., “A novel monoclonal antibody against human CD80 and its immune protection in a mouse lupus-like disease," International Journal of Immunopathology and Pharmacology, vol. 24, no. 3, pp. 583593, 2011.

[150] C. J. Rivard, T. Tanabe, M. A. Lanaspa et al., "Upregulation of CD80 on glomerular podocytes plays an important role in development of proteinuria following pig-to-baboon xeno-renal transplantation - an experimental study," Transplant International, vol. 31 , no. 10, pp. 11641177, 2018.

[151] J. Muller-Deile and M. Schiffer, "Podocytes from the diagnostic and therapeutic point of view," Pflügers Archiv, vol. 469, no. 7-8, pp. 1007-1015, 2017.

[152] S. Minamikawa, K. Nozu, S. Maeta et al., "The utility of urinary CD80 as a diagnostic marker in patients with renal diseases," Scientific Reports, vol. 8, no. 1, p. 17322, 2018.

[153] B. Zhao, H. Han, J. Zhen et al., "CD80 and CTLA-4 as diagnostic and prognostic markers in adult-onset minimal change disease: a retrospective study," PeerJ, vol. 6, article e5400, 2018.

[154] H. M. Ahmed, D. A. Ezzat, N. A. Doudar, and M. Adel, "Urinary CD80 as a replacement for renal biopsy for diagnosis of pediatric minimal change disease," Iranian Journal of Kidney Diseases, vol. 12, no. 2, pp. 107-111, 2018.

[155] D. Bhatia, A. Sinha, P. Hari et al., "Rituximab modulates Tand B-lymphocyte subsets and urinary CD80 excretion in patients with steroid-dependent nephrotic syndrome," Pediatric Research, vol. 84, no. 4, pp. 520-526, 2018.

[156] G. Cara-Fuentes, M. Venkatareddy, R. Verma et al., "Glomerular endothelial cells and podocytes can express CD80 in patients with minimal change disease during relapse," Pediatric Nephrology, vol. 35, no. 10, pp. 1887-1896, 2020. 
[157] P. Chen, Y. Chen, M. Jiang et al., "Usefulness of the cytokines expression of Th1/Th2/Th17 and urinary CD80 excretion in adult-onset minimal change disease," PeerJ, vol. 8, article e9854, 2020.

[158] A. M. Gonzalez Guerrico, J. Lieske, G. Klee et al., "Urinary CD80 discriminates among glomerular disease types and reflects disease activity," Kidney International Reports, vol. 5, no. 11, pp. 2021-2031, 2020. 